\title{
Appendix Two
}

\section{Grave types: diagrams}

Specifications of the grave itself were subject to a great deal of discussion and controversy, from the publication of guidance to burial boards in 1852 onwards. These diagrams illustrate some of the grave types discussed in the text.

\section{Figure 1}

a

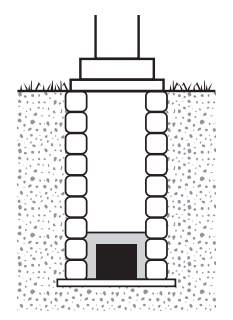

b

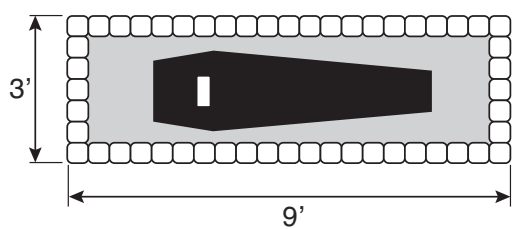

C

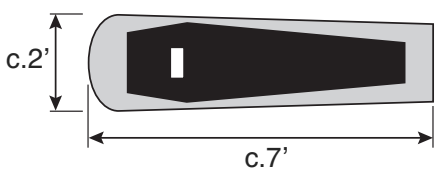




\section{Appendix Two}

Figure 2

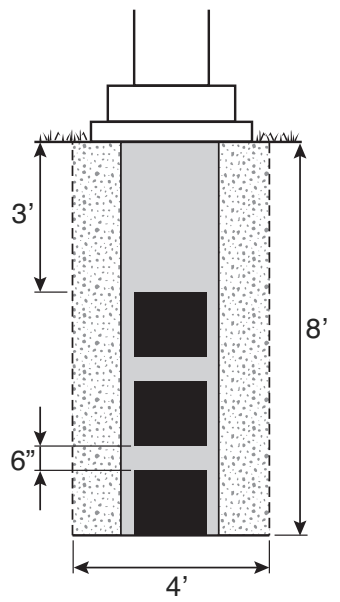

Figure 3

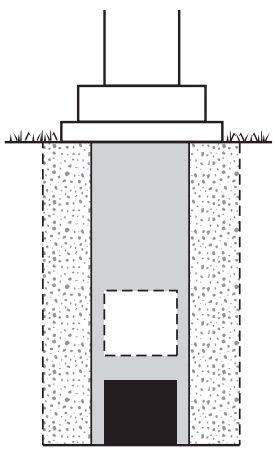

Figure 4

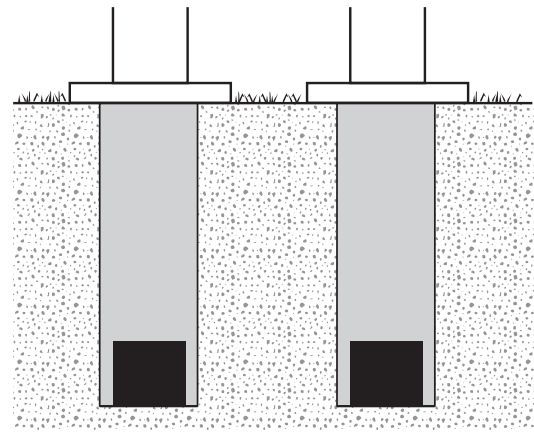

Note on depth: For churchyard burial there is no legislative requirement on the depth of the grave. For cemeteries, 1852 guidance indicated that for adults $4 \mathrm{ft}$ of soil above the coffin comprised was a suitable depth, with a foot of soil between each coffin where multiple interments took place. This was later reduced to $6 \mathrm{in}$. The depth of graves generally depends on the intended number of interments. 


\section{Appendix Two}

\section{1a and $b$. Bricked graves}

According to the Burial, Funeral and Mourning Reform Association, the bricked grave prevented the reuse of ground in the churchyard, as it would be unlikely that authorities dismantling any building under the ground would be viewed favourably. The Association also argued that brick graves took up more space than a normal earth grave (1c) but 1852 guidance later specified that $9 \mathrm{ft}$ by $4 \mathrm{ft}$ should be the standard plot size.

\section{1c. Earth grave}

A grave just a few inches larger than the coffin was commonplace in churchyards, but was superseded by graves located centrally within much specified plots (as at 5) in burial board cemeteries and in later churchyard extensions.

\section{Triple earth grave, full}

This grave has been dug to a depth sufficient to accommodate three interments. Each successive burial does not disturb the last, as gravediggers will be able to calculate achievable depth on the number of previous interments.

\section{Double earth grave, with space for a 're-open'}

This grave has remaining space for one further burial.

\section{Double grave, churchyard}

Double graves in churchyard often comprise two single burials side by side, rather than having both interments in one deeper grave, as at 2 . 